\title{
Development of Educational Support System for Algorithm using Flowchart
}

\author{
Masashi Ohchi Member (Saga University, masashi@ace.ec.saga-u.ac.jp) \\ Norio Aoki Student Member (Saga University, aoki@ace.ec.saga-u.ac.jp) \\ Tatsuya Furukawa Member (Saga University, tach@ace.ec.saga-u.ac.jp) \\ Kanta Takayama Non-member (FANUC LTD.)
}

Keywords: flowchart, education support system for algorithm, source code, compile, graphical user interface

Recently, an information technology is indispensable for the business and industrial developments. However, it has been a social problem that the number of software developers has been insufficient. To solve the problem, it is necessary to develop and implement the environment for learning the programming language and algorithm. In the paper, we will describe the algorithm study support system for a programmer based on flowchart. Since the implemented system uses Graphical User Interface(GUI), it will become easy for a programmer to understand the algorithm in programs.

Figure 1 shows the functions of algorithm study support system using the flowchart. It is able to make the source code from flowchart and to show the animations of the data sort algorithms.

Figure 2 shows the overview of present system. The user is able to create the flowchart using the original GUI.

Figure 3 shows the snapshot to study the algorithm based on the programming language. Using the system, when the user clicks the mouse button on the symbol of the flowchart, the $\mathrm{C}$ source codes are highlighted in the right side windows. Therefore, he can study both the algorithm and C source codes easily and simultaneously.

Figure 4 shows the snapshot of an animation mode window of the bubble sort. The user can see and study the sort algorithm by using animation.

It is considered that the implemented system uses the new GUI, it becomes easy for a programmer to understand the algorithm using the flowchart.

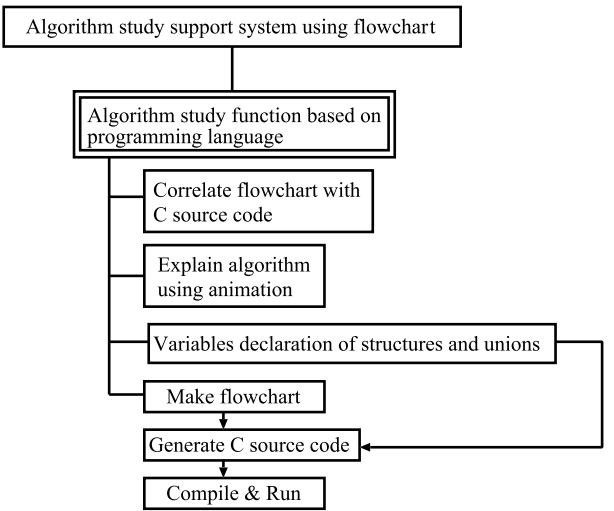

Fig. 1. Functions of algorithm study support system using flowchart

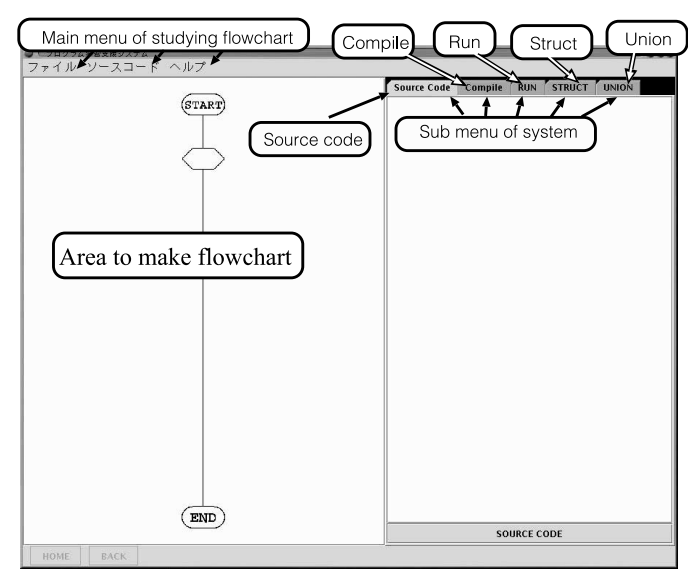

Fig. 2. Overview present system

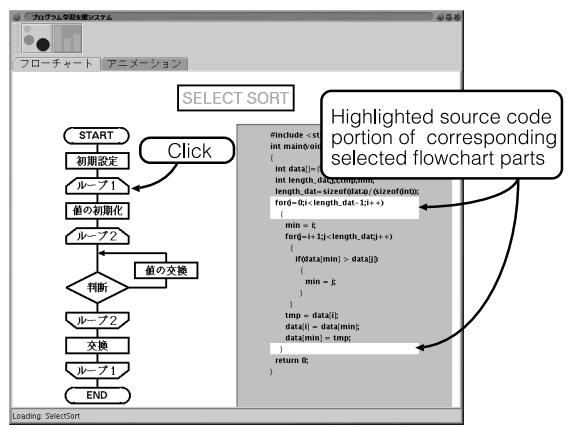

Fig. 3. Flowchart and program(selection sort)

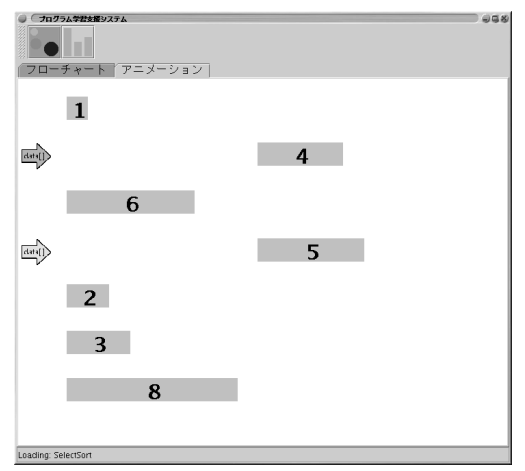

Fig. 4. Animation mode window 


\title{
フローチャートを利用したアルゴリズム学習支援システムの開発
}

\author{
正 員 相知 政司* 学生員 青木 規至* \\ 正 員 古川 達也* ${ }^{*}$ 非会員 高山 堪太**
}

Development of Educational Support System for Algorithm using Flowchart

Masashi Ohchi*, Member, Noriyuki Aoki*, Student Member,

Tatsuya Furukawa*, Member, Kanta Takayama**, Non-member

Recently, an information technology is indispensable for the business and industrial developments. However, it has been a social problem that the number of software developers has been insufficient. To solve the problem, it is necessary to develop and implement the environment for learning the algorithm and programming language. In the paper, we will describe the algorithm study support system for a programmer using the flowchart. Since the proposed system uses Graphical User Interface(GUI), it will become easy for a programmer to understand the algorithm in programs.

$$
\begin{aligned}
& \text { キーワード : フローチャート , アルゴリズム学習支援システム , ソースコード, コンパイル , グラフィカル・ユーザ・インタ } \\
& \text { フェース }
\end{aligned}
$$

Keywords: flowchart, education support system for algorithm, source code, compile, graphical user interface

\section{1. はじめに}

近年 , IT 技術の発展に伴い, IT 技術は社会基盤には，必 要不可欠なものとなっている。この結果，樣々な場所でプ ログラムが使われ，IT 技術者の不足が社会問題 ${ }^{(1)}$ になっ ている。乥こで, プログラムを作成できる技術者の育成が 必要となっている。

筆者らの経験から，大学の教育の場においても，プログ ラミングができない学生が年々増加していると感じている。 この大きな原因の 1 つが , 大学入試センター試験のような マークシートによる受験機会か増え, 受験対策として, 数 学や物理の問題でさえも暗記科目のように扱われ，暗記し た公式を用いて早く答えを出すという傾向か強いからでは ないかと考える。したがって，高等学校までの教育におい て, 問題の内容を理解し, 問題を分析・整理して, 導出過程 を論理的に考え，答えを導き出すことが疎かになっており， 論理的思考能力, 展開能力, 応用能力を涵養するような教

\footnotetext{
* 佐賀大学理工学部電気電子工学科

于 840-8502 佐賀市本庄町 1 番地

Department of Electronics Faculty of Science and Engineering, Saga University

1, Honjo-machi, Saga 840-8502

**ファナック (株)

= 401-0597 山梨県南都留郡忍野村忍草字古馬場 3580 番地

FANUC LTD

3580, Shibokusa Aza-Komanba, Oshino-mura, Minamitsurugun, Yamanashi Pref., 401-0597
}

育が行われていないと思われる。さらに, 入学試験には時 間的制約があり，一つの問題に対して時間をかけてじっく り考えて取り組むことは不利になる。光の結果，未知の問 題を解く場合に，集中力や忍耐力が不足していると思われ る。このような背景から, 近年の大学生は, プログラミン グ学習が苦手となっているのではないかと考えられる。

しかし，一方，近年の大学生は，初等教育からコンピュー タを使用した授業があり，弚の操作に慣れている。また，本 をあまり読まず，教科書の活字を読むより，コンピュータ を用いて学習した方が教育効果が向上するのではないかと 考えられる。

乥こで筆者等は, プログラミング学習の基礎的なものと して，フローチャートを用いたアルゴリズム学習支援シス テムを開発することにした。

フローチャートは手順や処理の流れを説明するために用 いられ，筆者等が行う情報処理教育の中でも，アルゴリズ ムが分かっている教員側が, 分かっていない学生に対して 説明する場合に, 多用されている。また, フローチャート はプログラムの基本的な構造をイメージするために利用さ れ，アルゴリズムは使用するプログラミング言語が変わっ ても同じである場合がほとんどである。

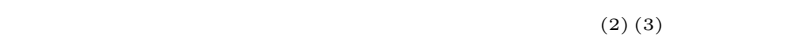
ローチャートからソースコードを生成し, コンパイル・実行 するような機能を実装していなかった。この点は, 実際に フローチャートを用いてアルゴリズムを学習しても，作成 したアルゴリズムの動作を確認することが困難であり，学 
習上大きな問題であった。

一方 , 山本氏によって ,プログラミング学習支援システム の利用が報告 ${ }^{(4)}$ されているが , フローチャートからソース コードを生成しコンパイルすることはできず，フローチャー トとソースコードを対応させた説明や変数の值を変更する 程度であった。

乥こで, 本研究では, 電気電子および情報系学科の大学 生を対象として，フローチャートを利用することで，アル

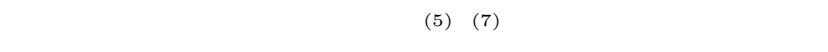
らに, 本システムでは, アニメーションを利用しソートアル ゴリズムの基本動作をイメージさせ理解させる工夫をした。

また , 本システムでは, アルゴリズムを確認するために フローチャートから C 言語のソースコードを生成し , コン パイル可能とした。次に, 学習者にとって難解な $\mathrm{C}$ 言語の 構造体と共用体について簡単に変数を宣言でき, 対応する $\mathrm{C}$ 言語のコードを生成可能とした。

本システムはJava アプリケーション ${ }^{(8)}$ として開発したの で, Java 2 Standard Edition (J2SE) Software Development Kit (SDK) もしくは J2SE Java Runtime Environment (JRE) ${ }^{(9)(10)}$ がインストールされているコンピュータ であれば，動作環境に合わせて若干コードを書き換えるだけ で, ほとんどのコンピュータで動作可能である。したがって， 多くの大学の情報処理演習室で利用されている Microsoft 社の Windows 系 OS や Apple 社の Mac OS , サーバ等 の用途で用いられる UNIX でも利用可能であり，学習者が 著作権を気にせず，ライセンス料を支払うこともなしに使 用可能である。したがって，本システムは，プログラミン グ学習者にとってアルゴリズムを学習するには, 有用かつ 有益なシステムであると考えられる。

\section{2. アルゴリズム学習支援システム}

「プログラム言語アルゴリズム学習機能」について，光の 使用の流れを図 1 に示す。また , 本システムの主な機能は， 以下の通りである。

・フローチャートとソースコードの対応を見ることによっ て , フローチャートとアルゴリズムの関係について , 同 時に説明が可能。

・ソートプログラムについてフローチャートを用いて表 し，アニメーションを利用して単純なソートアルゴリ ズム ${ }^{(11)}$ の説明が可能。

-構造体や共用体の変数宣言について学習可能。

・フローチャートからソースコードを生成し，コンパイ ル後に実行し動作確認が可能。

これらの機能を用いることによってプログラミング学習 者か視覚的かつ能動的にアルゴリズム学習ができる。

〈2. 1〉 プログラム言語アルゴリズム学習機能 プロ グラム言語アルゴリズム学習機能の概観を图 2 に示す。本 システムには, フローチャートとプログラムを対応させた フローチャート・モードとソートの樣子をアニメーション
Algorithm study support system using flowchart

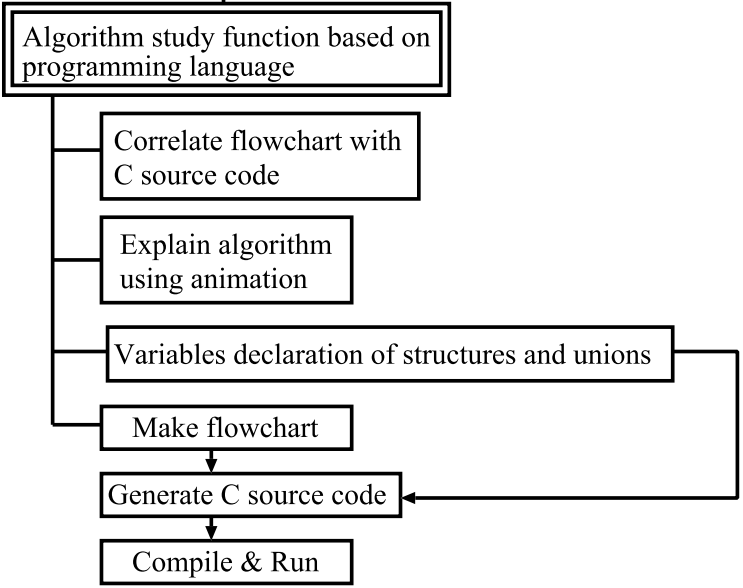

図 1 システムの機能

Fig. 1. Function of system.

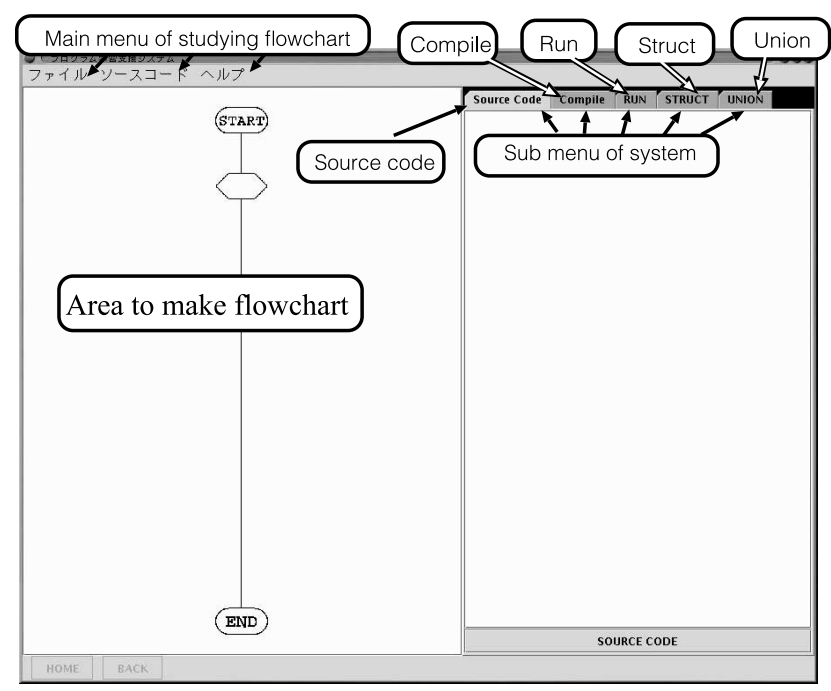

図 2 システムの概観

Fig. 2. Overview of present system.

で表すアニメーション・モードがある。さらに, 学習者が 自由にフローチャートを作成可能であり，作成したフロー チャートから C 言語のソースコードを生成, コンパイル . 実行するモードがある。

〈2. 2〉フローチャート・モード（図 3 に, 単純選択 ソートのフローチャート・モードを示す。フローチャート・ モードでは, フローチャートとプログラムを表示する。図 3 のフローチャートのブロック部分をクリックすると , ブ ロックに対応したプログラムのソースコード部分の背景色 が白に変わる。

これによって，フローチャートとプログラムを関連付け て考えることができ，アルゴリズム学習に利用できると考 えられる。

〈2.3〉 アニメーション・モード＼cjkstart本システムでは, プ ログラム学習者に説明する最初のアルゴリズム例としてバ 


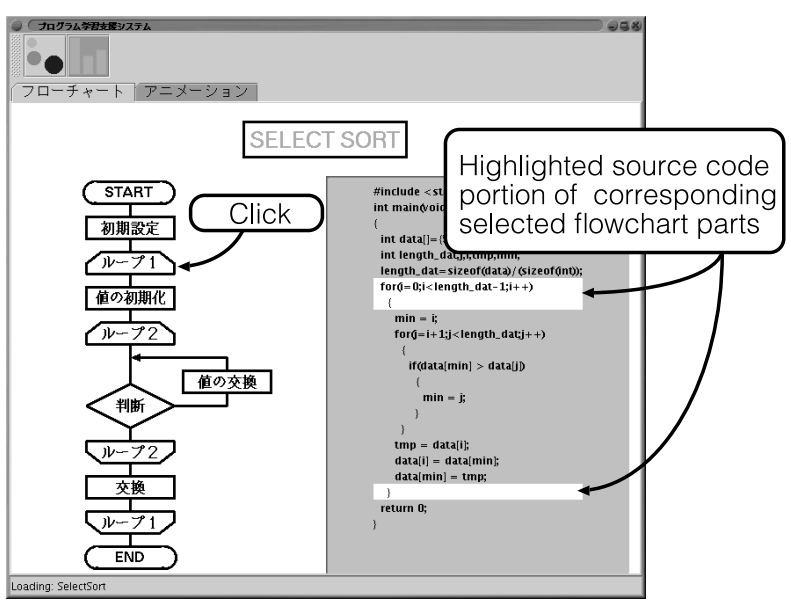

図 3 フローチャートとプログラム (選択ソート)

Fig. 3. Flowchart and program(selection sort).

ブルソート，単純選択ソートのアニメーションによる説明 を実装した。両者を文章で説明すれば，以下のようになる が，アニメーションによる説明であれば，視覚的情報であ り学習者にとって容易に理解可能になると考えられる。

・バブルソート

配列の後ろから先頭に向かってスキャンしていき，も し隣り合う二つの要素の大小関係が逆であったら，光 れを入れ換えるという単純なものである。

最初は, $n-1$ 番目 (最後) から 0 番目 (先頭) の要 素までをスキャンする。产の結果, 最小の要素が 0 番 目 (先頭) に浮かび上がってくる。二回目のスキャンで は, $n-1$ 番目 (最後) から 1 番目までの要素をスキャ ンして, 結果として次に小さい要素が配列の 1 番目に 浮かび上がってくる。更に，スキャンを繰り返してい き，最終的に $n-1$ 回目のスキャンで整列が完了する。

・単純選択ソート

単純選択ソートはデータの中で最小の值を選択し， 最小の値をデータの先頭に移動する。乥の後データの 先頭 +1 からデータの最後までで最小の值を選択し，乥 の值をデータの先頭 +1 の値と交換する。以上の動作 を繰り返すことによって , データが先頭から小さな順 に並んで行く。

図 4 にバブルソートのアニメーション・モードを示す。 アニメーション・モードでは, データがソートされている のが視覚的に理解でき, ソートのアルゴリズムを理解する のに効果があると考えられる。

実際には，データの大きさに対応した四角形を表示し， ターゲットになっているデータ二個が右側に移動し比較が 行われる。バブルソートの場合は, 上のデータが大きい時 には, 入れ換えが発生し, 弚れ以外の場合には, 弚のまま 左に移動する。この動作をデータのソートが終了するまで 続ける。

〈2.4〉 構造体と共用体の変数宣言 プログラム学習者 にとって構造体と共用体を授業で学習しても，变数の宣言

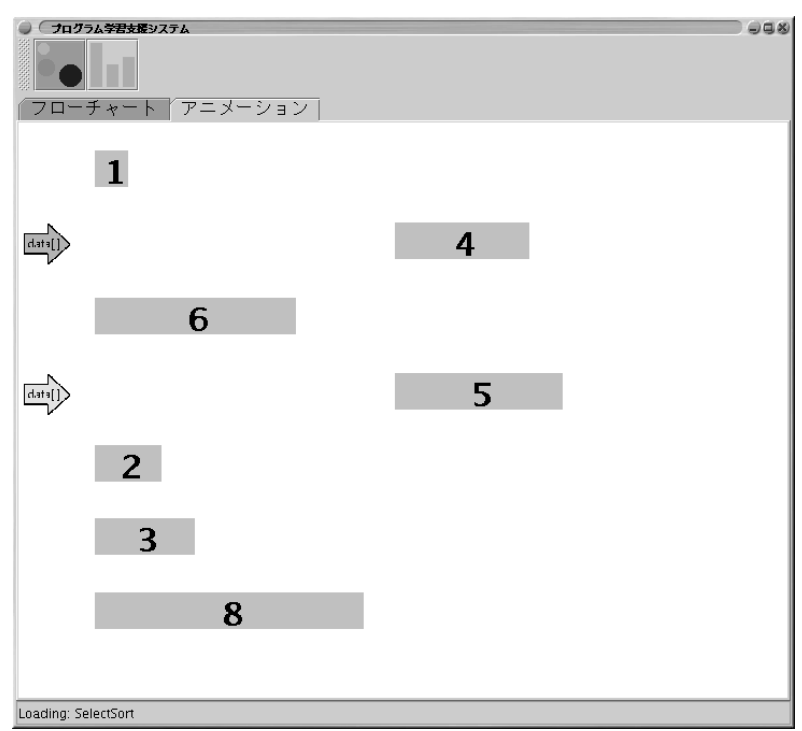

図 4 アニメーションモード

Fig. 4. Animation mode.

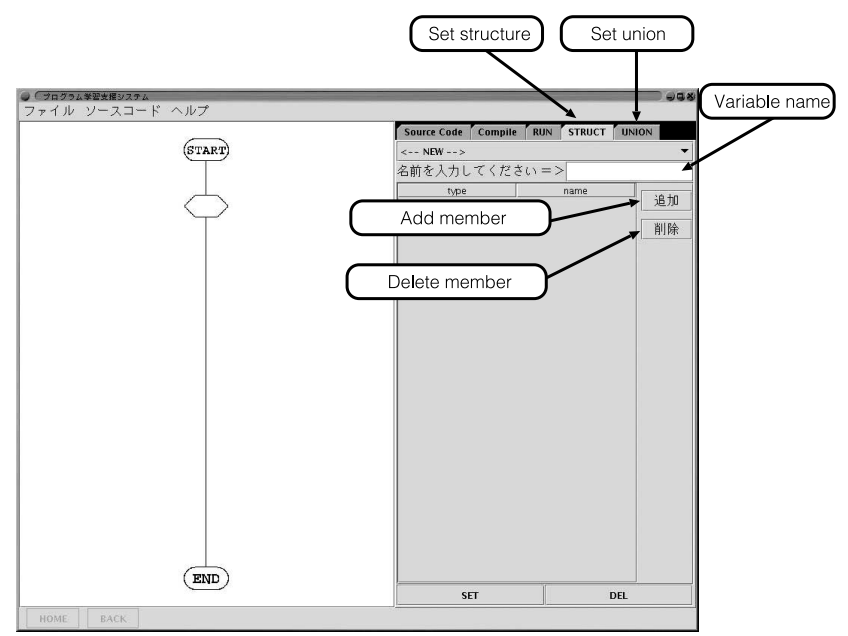

図 5 構造体設定

Fig. 5. Setting window for structure variable.

さえもできないことがある。光こで, 本システムでは, 構 造体と共用体変数の変数宣言をサポートする学習項目を実 装した。

图 5 に構造体の設定画面を示す。図 5 のシステムメニュー から “STRUCT” タブを選択すると，構造体の設定を行う ことができ，“UNION” タブを選択すると，共用体の設定 を行うことができる。この設定画面では, 構造体の名前設 定・メンバの追加・メンバの削除を行うことができる。

まず，追加ボタンをクリックすると追加ウィンドウが表示 される。弚の後，メンバの作成を行い OK ボタンをクリッ クすると，図 6 のようにメンバの作成が行われる。

〈2.5〉 ソースコード出カモード 図 2 に示したサブ メニューにある “Source Code” タブをクリックすると， フローチャートに対応したソースコードが表示される。

图 7 に本システムを使用して作成したフローチャートの サンプルを示す。本図を元に生成されたソースコード表示 


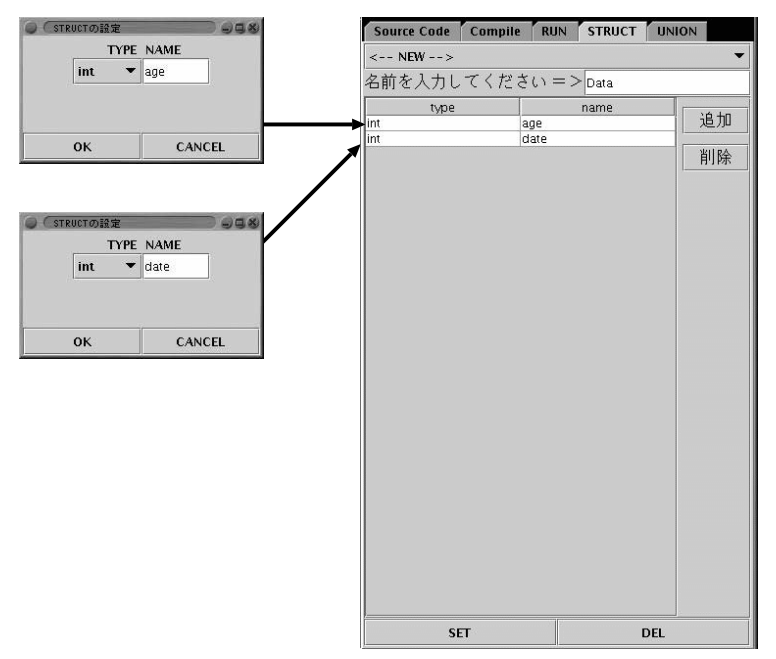

図 6 構造体の設定結果

Fig. 6. Result in setting structure variable.

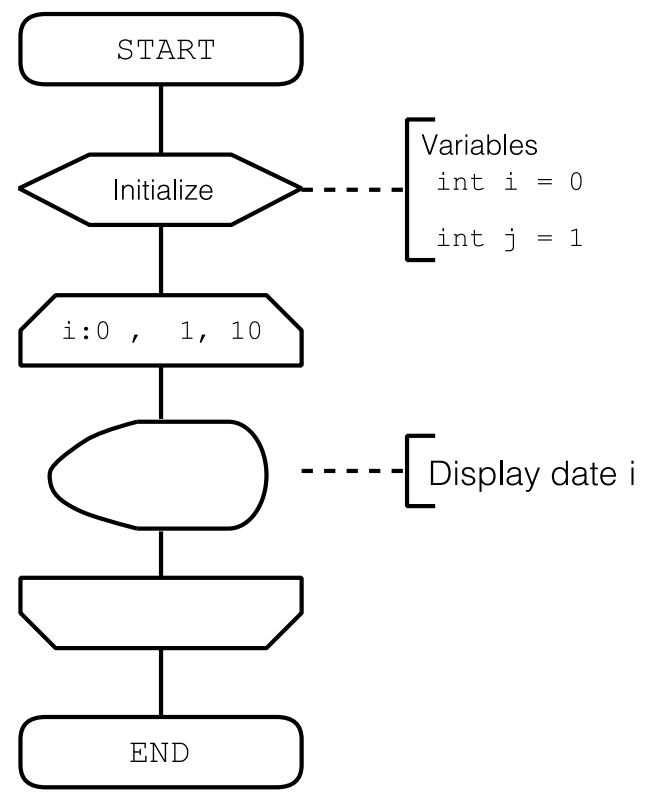

図 7 ソースコードを生成するための フローチャート

Fig. 7. Flowchart for generating source code.

ウィンドウを図 8 に示す。ただし，実際には，フローチャー トから全てのソースコードか完全に生成可能ではないので， 事前に変数名等をユーザが入力しておく必要がある。

〈2.6〉 コンパイル・実行モードコンパイル・実行 モードは, 前節で説明したソースコードを利用しプログラ ムのコンパイル・実行を行う。

コンパイルは図 2 に示したフローチャートシステムから “Compile” タブを選択し, 图 9 に示すコンパイルボタン を押し実行する。コンパイル時にエラーがある場合には，エ ラーコードが表示され，エラーがない場合は,「コンパイル 完了」と表示される。

プログラムの実行はフローチャートシステムから “Run” タブを選択し，図 10 に示す「実行」ボタンを押し実行す

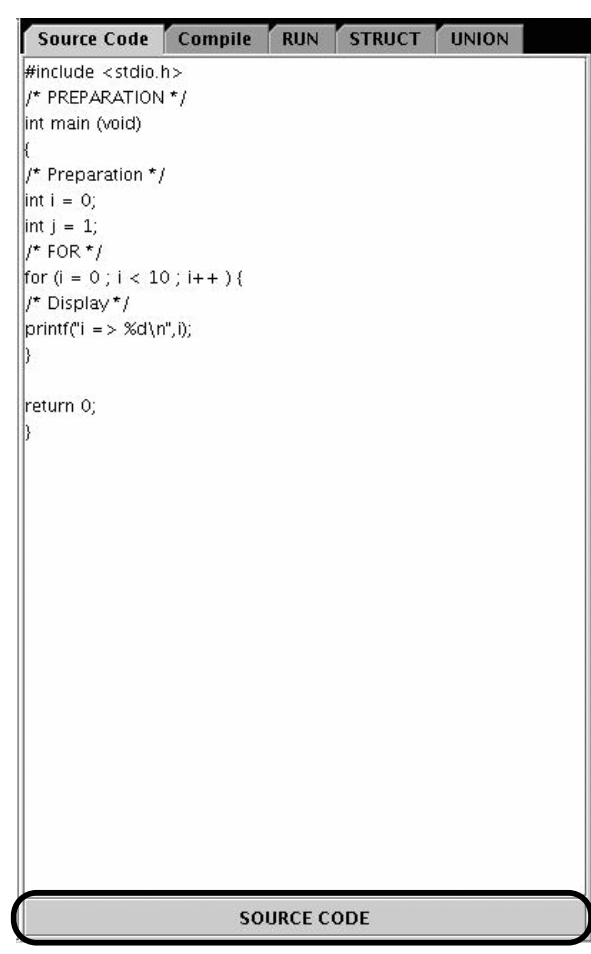

図 8 ソースコードの出力

Fig. 8. Generated source code.

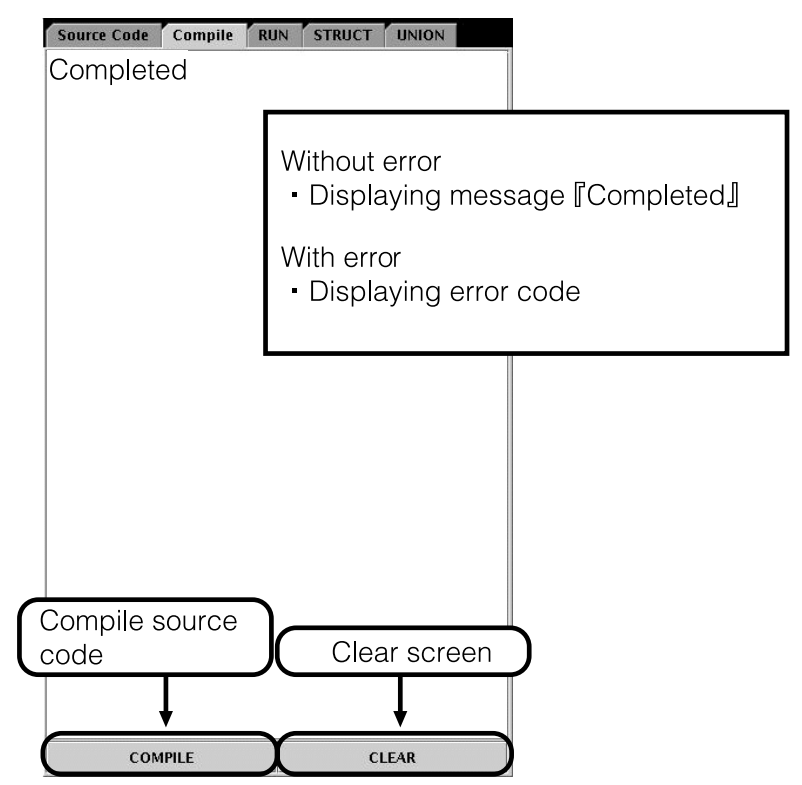

図 9 コンパイル

Fig. 9. Compile.

る。実行時に表示される標準出力は実行画面に表示される。 〈2.7〉 本システムの有用性 大学の授業では, 毎回 の授業が 90 分で, 学期あたり 15 回の授業を行い評価を行 う場合が多い。この場合, 授業時間の都合で, 授業内容が アルゴリズムとプログラミング文法のどちらかに主眼をお くことになりがちであるが，本システムを使用すれば，フ ローチャートを利用しながらアルゴリズムを学習の中心と することが可能である。 


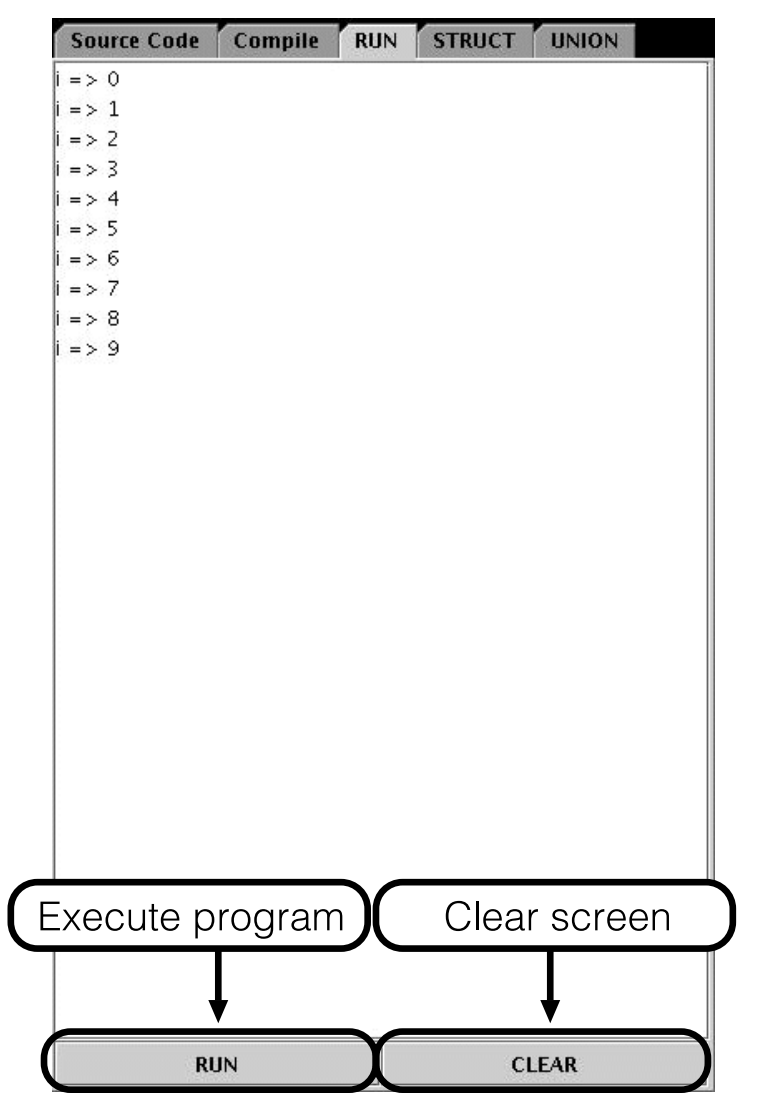

図 10 実行

Fig. 10. Running.

さらに , アルゴリズムを検証するためには , ソースコー ドをコンパイルして実行することが必須である。本システ ムでは, アルゴリズムに対応するソースコードを生成可能 なので, プログラミング文法も同時に学習可能である。ま た，自動生成されたソースコードを利用すれば，文法エラー か理解できずに無駄な時間を過こすすといったプログラム学 習者にありがちな事例が少なくなり，学習内容に集中でき るので教育効果の向上が期待される。したがって , プログ ラム学習者のアルゴリズム学習に大変有効かつ有用である と考えられる。

\section{3. 本システムの使用予定授業}

開発した本システムを, 当学科の 3 年次生を対象とした 平成 18 年 10 月に開講される後学期選択科目である「アル ゴリズム論」にて，使用する予定である。

当学科のカリキュラムでは, 1 年次の後学期必修科目「情 報基礎演習 II」で簡単な $\mathrm{C}$ 言語の文法とコンパイルと実行 の仕方を学習し， 2 年次後学期必修科目「プログラミング 演習」で, ベクトルの演算, 行列式の計算や簡単な数值積 分などのプログラミング実習を行っている。

3 年次後学期の選択科目「アルゴリズム論」では， $\mathrm{C}$ 言 語のコンパイルや文法はある程度理解しているとの前提で， 「アルゴリズム」に重点をおいた授業を行う予定である。ま た，本授業は，情報処理演習室において行うので, 学生は
各自 1 台ずつパソコンを使用できる。

この「アルゴリズム論」で, フローチャートとソースコー ドの対応 , ソートプログラムにおけるアルゴリズムの違い による実行速度の変化などを教授する予定であり, 従来のテ キストなどを用いる紙媒体中心の授業と比較して，フロー チャートからソースコードを生成することも可能で, アル ゴリズムに関する学生の理解も深まり, プログラミングに 対する興味も増加するものと考える。

本授業を通して，開発したシステムの教育効果を検証し， 今後の改善に生かす予定である。

\section{4. むすび}

本研究では, プログラム学習者のためにフローチャート を利用したアルゴリズム学習支援システムを開発した。

フローチャートとソースコードを対応させて表示するこ とによって, プログラム学習者にとって, ソースコードを 理解する場合にも利用できる。さらに，アニメーションを 利用することにより，データソートのアルゴリズムを視覚 的に簡単に理解できると考えられる。

さらに, 本システムでは, $\mathrm{C}$ 言語の構造体や共用体の変 数宣言やフローチャートから $\mathrm{C}$ 言語のソースコード生成が でき, プログラム学習者にとって , アルゴリズム , フロー チャート，ソースコードを対応させて同時に学習すること が可能であり，従来の教科書だけを用いた授業と比較して， 教育効果の向上が期待される。

最後に, 本システムのソフトウェアは Java アプリケー ションとして開発したので, J2SE SDK もしくは J2SE JRE がインストールされているコンピュータであれば，ほ とんどのコンピュータで動作可能である。さらに，著作権 に抵触することなしに無料で, 大学の情報処理演習室や家 庭での自学習にも利用可能であり，大学等の情報処理教育 において有用なシステムを開発できたと考えられる。

今後の課題としては，実際の授業て使用し，ユーザの意見 を聞いた上でGUI の改善や課題の提出などが挙げられる。

謝 辞

本研究を遂行するにあたり，2005 年 3 月に佐賀大学大学 院工学系研究科博士前期課程電気電子工学専攻を修了した (現 : アイコム株式会社勤務) 赤木圭太氏に多大な協力を頂 いた。ここに，謝意を表する。

(平成 17 年 8 月 25 日受付, 平成 18 年 7 月 19 日再受付)

$$
\text { 文献 }
$$

（1）総務省・情報通信行政·情報通信ソフト懇談会,http://www. soumu.go. jp/joho_tsusin/policyreports/chousa/soft tkondan/

（2）高山堪太・相知政司・古川達也：「Java を用いたロボット制御アル ゴリズムの学習支援システム構築の試み」, 第 11 回 電子情報通信 学会九州支部学生会講演論会, No.D2-24, pp.123 (2003-9)

( 3 ) K. Takayama, M. Ohchi, and T. Furukawa: "Development of Algorithm Study Support System by Flow-chart Creation using Java", SICE Kyushu Branch Annual Conference, Vol.22, No.203A6, pp.259-260 (2003-11) (in Japanese) 高山堪太・相知政司・古川達也 : 「Java を用いたフローチャート作 
成によるアルゴリズム学習支援システムの開発」, 第 22 回 SICE 九州支部学術講演会, 203A6, pp.259-260 (2003-11)

(4) Y. Yamamoto: "Use of the Programming Learning Support System Simultaneously Displaying the Flow Chart and the Source Code", Trans. Japanese Soc. Information \& System in Education, Vol.20, No.4, pp.380-384 (2003) (in Japanese) 山本 芳人:「流れ図とソースプログラムを対応させたプログラミング学 習支援システムの利用」, 教育システム情報学誌 $, \mathbf{2 0}, 4, \mathrm{pp} .380-384$ (2003)

( 5 ) K. Takayama, M. Ohchi, and T. Furukawa: "Proposal for Algorithm Study Support System using Flowchart", The Papers of Joint Technical Meeting on Frontier in Education, IEE Japan, FIE-04-16, pp.9-12 (2004-3) (in Japanese)

高山堪太・相知政司・古川達也 : 「フローチャートを利用したアルゴ リズム学習支援システムの提案」, 電気学会教育フロンティア研資, FIE-04-16 , pp.9-12 (2004-3)

（6） 高山堪太・相知政司・古川達也 : 「フローチャート作成によるプログ ラミング言語学習支援システムの開発」平 16 電気関係学会九州支 部連大 , 12-2A-02, pp.630 (2004-9)

( 7 ) K. Takayama, M. Ohchi, and T. Furukawa: "Development of C Language Study Support System by Flow-chart Creation", SICE Kyushu Branch Annual Conference, No.203C5, pp.297298 (2004-12) (in Japanese)

高山堪太・相知政司・古川達也 : 「フローチャート作成による C 言 語学習支援システムの開発」, 第 23 回 SICE 九州支部学術講演会, 203C5, pp.297-298 (2004-12)

(8) 坂田健二 : JAVA プログラミング入門，秀和システム (2005)

(9) http://java.com/ja/

（10）柏原正三 : 標準プログラマーズライブラリシリーズ , ひとりででき る Java 実践入門，技術評論社 (2003)

（11） 柴田望洋・辻 亮介：C 言語によるアルゴリズムとデータ構造， SOFT BANK (2002)

相 知 政 司 (正員) 1964 年 12 月 8 日生。1989 年 3 月長崎

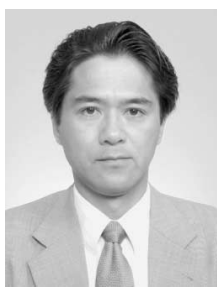
大学大学院工学研究科修士課程修了。同年 4 月 NTT に入社。1991 年 4 月佐賀大学理工学部助手。 1993 年 4 月同電子工学科助手入配置替。 2000 年 4 月同電気電子工学科講師。2002 年 1 月同助教 授。現在に至る。分布誘電率推定に関する研究並 びに教育工学に関する研究に従事。博士 (工学)。 計測自動制御学会, 電子情報通信学会, 日本シミュ
青 木 規 至 (学生員) 1981 年 5 月 20 日生。2004 年 3 月佐

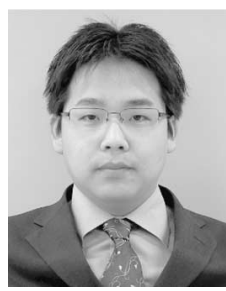
賀大学理工学部電気電子工学科卒業。同年 4 月同 大学大学院工学系研究科博士前期課程電気電子工 学専攻入学。2006 年 3 月同専攻修了。同年 4 月 同大学大学院工学系研究科博士後期課程システム 生産科学専攻進学。電磁界の計測並びにWeb と データベースを応用したシステムに関する研究に 従事。計測自動制御学会, 日本音響学会学生員。

古 川 達 也 (正員) 1956 年 6 月 21 日生。1984 年 3 月九州 大学大学院工学研究科博士後期課程単位修得上退 学。同年 4 月長崎大学工学部助手。1986 年佐賀 大学理工学部電気工学科講師。1987 年同助教授。 1993 年 4 月同電子工学科助教授人配置替。 2001 年 4 月電気電子工学科教授。現在に至る。数值解 析, 計算機応用工学に関する研究に従事。工学博 士。計測自動制御学会, 日本シミュレーション学 会, 日本 AEM 学会, 電子情報通信学会, 情報処理学会会員。

高 山 堪 太 (非会員) 1980 年 12 月 25 日生。 2003 年 3 月佐

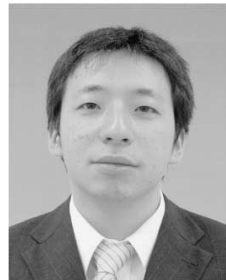
賀大学理工学部電気電子工学科卒業。同年 4 月大 大学院博士前期課程進学。2005 年 3 月同大大学 院博士前期課程修了。同年 4 月ファナック (株) 入社, 現在に至る。在学中は, フローチャートを 援用したアルゴリズム学習支援システムの開発に 従事。

レーション学会, 日本 AEM 学会, 日本ロボット学会会員 